\title{
Pengaruh Faktor Sosial Demografi dan Kinerja Polisi terhadap Kepercayaan Masyarakat kepada Polisi di Indonesia Tahun 2017
} \author{
Indonesia in 2017) \\ Dina Rahmawati ${ }^{*}$, Rini Silvi ${ }^{2}$ \\ 1,2 Politeknik Statistika STIS \\ Jl. Otto Iskandardinata No. 64 C Jakarta 13330, Jakarta, Indonesia \\ E-mail:211709632@stis.ac.id
}

(Influence of Social Demographic Factors and Police Performance on Public Trust in Police in

\begin{abstract}
ABSTRAK
Selama tahun 2013-2017, tingkat kepercayaan masyarakat kepada polisi terus mengalami kenaikan. Meski demikian, masih banyak keluhan masyarakat mengenai kinerja polisi. Polisi menempati urutan pertama sebagai lembaga yang diadukan ke Komnas HAM selama lima tahun tersebut. Hal ini mengindikasikan bahwa terdapat faktor lain di luar kinerja polisi yang memengaruhi kepercayaan masyarakat kepada polisi. Penelitian ini bertujuan untuk mengetahui faktor sosial demografi dan kinerja polisi yang memengaruhi kepercayaan masyarakat kepada polisi di Indonesia beserta kecenderungannya. Penelitian ini menganalisis data Susenas September 2017 dari BPS dengan menggunakan analisis deskriptif dan analisis inferensia menggunakan metode regresi logistik biner. Hasil penelitian ini menunjukkan bahwa wilayah tempat tinggal, kegiatan utama, jenis kelamin, umur, tingkat pendidikan, status ekonomi, kekhawatiran terhadap tindak kejahatan, dan keterlibatan dengan lembaga hukum berpengaruh signifikan terhadap kepercayaan masyarakat kepada polisi di Indonesia. Kepolisian diharapkan dapat meningkatkan kinerja serta performanya terutama yang berhubungan langsung dengan masyarakat.
\end{abstract}

Kata kunci: kepercayaan masyarakat, polisi, regresi logistik biner

\begin{abstract}
During 2013-2017, the level of public trust in the police continued to increase. Nevertheless, there are still many public complaints about the performance of the police. The police ranked first as the institution complained to Komnas HAM for five years. This indicates that there are other factors beyond police performance that affect public trust in the police. This study aims to determine the socio-demographic and police performance factors that affect public trust in the police in Indonesia and their tendencies. This study analyzed Susenas September 2017 data from BPS using descriptive analysis and inference analysis using binary logistics regression method. The results showed that the area of residence, main activities, gender, age, level of education, economic status, concerns about crime, and involvement with legal institutions have a significant effect on public trust in the police in Indonesia. Police are expected to improve their performance and performance, especially those directly related to the community.
\end{abstract}

Keywords: public trust, police, binary logistic regression

\section{PENDAHULUAN}

Indonesia merupakan negara hukum sebagaimana tercantum dalam UUD 1945 pasal 1 ayat 3 sehingga hukum dijadikan dasar dalam dinamika kehidupan kenegaraan Indonesia. Sistem penegakan hukum di Indonesia dilaksanakan oleh beberapa lembaga penegak hukum, salah satunya adalah Kepolisian Republik Indonesia (Polri). Dalam menjalankan tugasnya, kepolisian membutuhkan kepercayaan dari masyarakat. Ketika masyarakat memandang polisi dapat dipercaya, maka kerjasama masyarakat dengan polisi dapat terjalin sehingga membantu efektifitas kinerja polisi (Goldsmith, 2005). Orang yang percaya kepada polisi cenderung akan melaporkan tindak kejahatan yang terjadi (Watkins, 2005).

Hasil survei Litbang Kompas tahun 2013 hingga tahun 2017 menunjukkan bahwa selama tahun tersebut tingkat kepercayaan kepada polisi terus meningkat. Tahun 2017, kepercayaan masyarakat kepada polisi sebesar 73,05 persen dan merupakan institusi dengan kepercayaan masyarakat tertinggi ketiga setelah Komisi Pemberantasan Korupsi (KPK) dan Tentara Nasional Indonesia (TNI). Hal tersebut menunjukkan bahwa kepolisian terus berupaya melakukan perbaikan untuk meningkatkan kepercayaan masyarakat. 


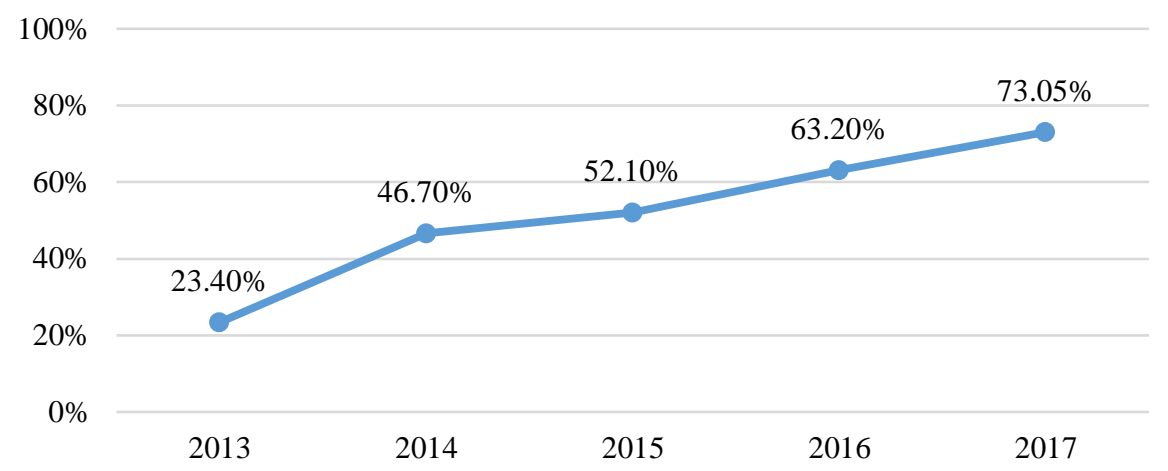

Sumber: Litbang Kompas, 2019

Gambar 1. Grafik kepercayaan masyarakat kepada polisi tahun 2013-2017

Meskipun kepercayaan masyarakat terus meningkat dari tahun ke tahun, keluhan masyarakat terkait kinerja polisi masih tergolong tinggi. Kepolisian menempati urutan pertama sebagai lembaga yang paling banyak diadukan kepada Komisi Nasional Hak Asasi Manusia (Komnas HAM) selama lima tahun berturutturut. Selama tahun 2013 hingga 2017, kepolisian mendapatkan keluhan jauh lebih tinggi dibandingkan lembaga pemerintah lainnya. Padahal sebagai lembaga penegak hukum, sudah sepatutnya seluruh anggota polisi berkewajiban dan bertanggung jawab dalam menegakkan HAM. Dari 5.387 berkas pengaduan yang diterima Komnas HAM tahun 2017, 1.652 berkas atau sekitar 30,67 persen berkas pengaduan tersebut ditujukan kepada polisi. Keluhan masyarakat terhadap polisi didominasi oleh masalah proses alur penyelidikan dan/atau penyelidikan sejumlah 1.265 berkas atau 75,57 persen dari berkas pengaduan yang ditujukan kepada polisi.

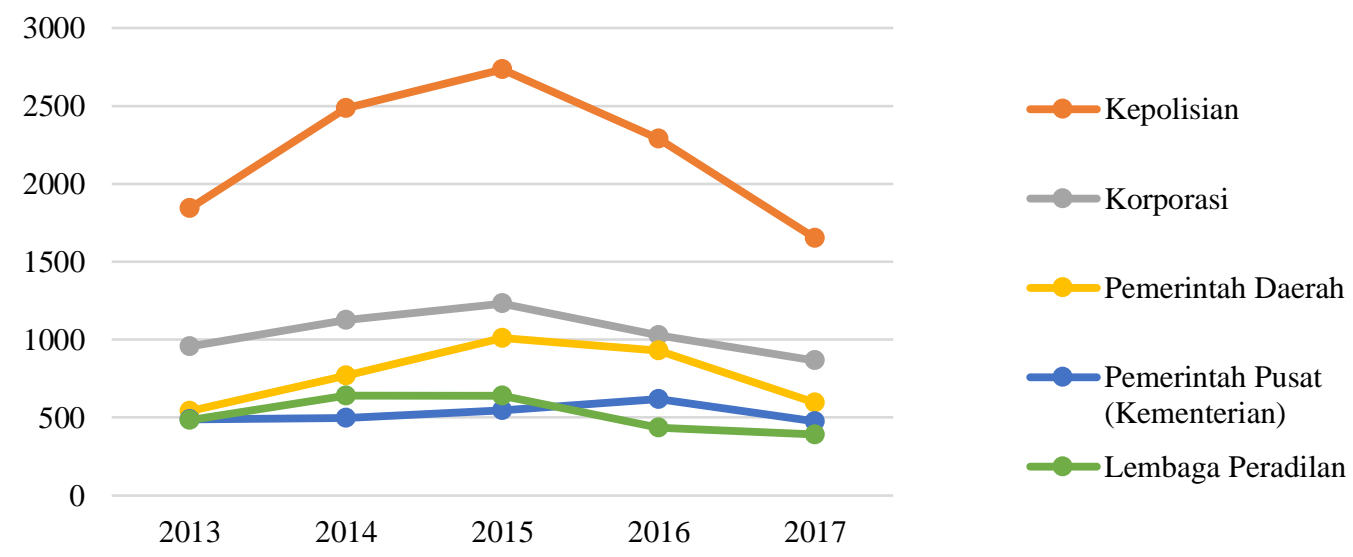

Sumber: Laporan Tahunan Komnas HAM, 2013-2017

Gambar 2. Grafik lembaga yang paling banyak diadukan kepada Komnas HAM tahun 2013-2017

Selain itu, berdasarkan publikasi tahunan Ombudsman Republik Indonesia (RI) tahun 2017, Kepolisian menempati urutan kedua setelah Pemerintah Daerah sebagai institusi yang paling banyak dilaporkan ke Ombudsman RI. Laporan ini terkait dugaan adanya maladministrasi dan didominasi oleh laporan tentang penundaan berlarut sebesar 45 persen dari laporan yang ada. Berdasarkan substansi laporan, kepolisian berada pada urutan ketiga terbanyak setelah pertanahan dan pendidikan.

Keluhan ini menunjukkan bahwa kinerja polisi dinilai tidak sesuai dengan prosedur atau harapan masyarakat sebagai pengadu. Berbagai laporan dugaan maladministrasi dan pengaduan HAM yang ditujukan kepada polisi menunjukkan bahwa efektivitas dan legitimasi kinerja polisi masih diragukan. Meski demikian, tingkat kepercayaan kepada polisi justru meningkat dari tahun ke tahun. Bahkan, menurut survei Litbang Kompas tahun 2017, polisi menempati urutan ketiga sebagai lembaga yang paling dipercaya masyarakat. Hal ini mengindikasikan bahwa kepercayaan kepada polisi tidak hanya dipengaruhi oleh kinerja polisi itu sendiri, melainkan dapat dipengaruhi faktor lain di luar kontrol polisi. Oleh karena itu, penelitian mengenai faktorfaktor yang memengaruhi kepercayaan kepada polisi di Indonesia penting untuk dilakukan.

Terdapat berbagai penelitian yang menunjukkan adanya pengaruh faktor sosial demografi masyarakat terhadap kepercayaan kepada polisi. Penelitian sebelumnya yang dilakukan oleh Alalehto \& Larsson (2016) 
di benua Eropa menunjukkan bahwa wilayah tempat tinggal, jenis kelamin, umur, kondisi ekonomi, tingkat pendidikan, dan kegiatan utama seseorang berpengaruh signifikan terhadap tingkat kepercayaannya kepada polisi. Selain itu terdapat faktor lain yang menunjukkan kinerja polisi seperti kontak dengan polisi dan kekhawatiran terhadap tindak kejahatan juga memiliki pengaruh signifikan terhadap kepercayaan kepada polisi (Lee et al., 2019; Malone \& Dammert, 2020; Ren et al., 2005). Sayangnya penelitian mengenai kepercayaan kepada polisi di Indonesia masih sangat sedikit seperti penelitian yang telah dilakukan Suwondo (2020) yang melakukan analisis deskriptif tentang tingkat kepercayaan masyarakat terhadap kinerja polisi. Penelitian lain dilakukan oleh Febrieta dan Pertiwi (2018), penelitian tersebut menggunakan regresi sederhana untuk mengetahui pengaruh rasa aman terhadap kepercayaan masyarakat tentang kehadiran polisi. Menurut sepengetahuan penulis belum ada penelitian yang membahas tentang pengaruh karakteristik sosial demografi penduduk terhadap kepercayaan kepada polisi. Oleh sebab itu peneliti tertarik untuk mengetahui pengaruh faktor sosial demografi masyarakat dan faktor kinerja polisi terhadap kepercayaan masyarakat kepada polisi di Indonesia.

Berdasarkan uraian sebelumnya, terdapat tiga tujuan dalam penelitian ini. Pertama, melihat gambaran umum kepercayaan terhadap polisi di Indonesia tahun 2017. Kedua, mengetahui variabel-variabel pada faktor sosial demografi dan faktor kinerja polisi yang memengaruhi kepercayaan kepada polisi secara signifikan. Ketiga, mengetahui bagaimana kecenderungan variabel-variabel tersebut terhadap kepercayaan kepada polisi di Indonesia tahun 2017.

\section{METODE}

Kepercayaan masyarakat adalah kepercayaan warga terhadap suatu institusi negara dan pemerintah, kebijakan publik, dan para pejabatnya (Dwiyanto, 2011). Menurut Bovens \& Wille (2008) kepercayaan masyarakat tidak hanya ditentukan oleh variabel yang ada di bawah kontrol institusi pemerintah, seperti kinerja, melainkan juga ditentukan oleh variabel yang di luar kendali institusi pemerintah, seperti kondisi ekonomi, perubahan antargenerasi, dan situasi dalam masyarakat. Menurut Wu et al., (2012) kepercayaan kepada polisi dapat dilihat dari beberapa sudut pandang. Sudut pandang pertama adalah sosial demografi, sudut pandang ini berpendapat bahwa kepercayaan seseorang terhadap polisi dipengaruhi oleh posisi demografi mereka di masyarakat. Sudut pandang kedua adalah kinerja institusi, kinerja suatu institusi berkaitan erat dengan kepuasan masyarakat terhadap institusi tersebut. Sudut pandang ketiga adalah budaya, nilai budaya dan norma merupakan salah satu faktor penting dalam membentuk perilaku dan opini masyarakat terhadap institusi terkait.

Berdasarkan penelitian sebelumnya, wilayah tempat tinggal berkaitan dengan kepercayaan polisi (Malone \& Dammert, 2020; Wu et al., 2012). Selain itu, kegiatan utama juga berpengaruh terhadap kepercayaan polisi dimana penduduk yang bekerja cenderung lebih percaya kepada polisi dibandingkan kegiatan utama yang lain (Alalehto \& Larsson, 2016; Kääriäinen, 2007). Penelitian terdahulu juga menyebutkan bahwa usia berkaitan dengan kepercayaan polisi di mana seseorang yang lebih tua cenderung lebih percaya kepada polisi yang dapat disebabkan oleh perbedaan kebutuhan dan tuntutan kepada polisi dari setiap generasi (Alalehto \& Larsson, 2016; Malone \& Dammert, 2020; Ren et al., 2005; Wu et al., 2012). Jenis kelamin juga berkaitan dengan kepercayaan terhadap polisi (Malone \& Dammert, 2020; Tankebe, 2010). Semakin tinggi tingkat pendidikan seseorang maka kepercayaan orang tersebut terhadap polisi cenderung rendah, hal ini dapat terjadi karena penduduk dengan pendidikan tinggi cenderung lebih kritis terhadap penyelewengan yang terjadi di kepolisian (Malone \& Dammert, 2020; Tankebe, 2010). Penduduk dengan status ekonomi rendah cenderung tidak mempercayai polisi (Malone \& Dammert, 2020; Wu et al., 2012). Seseorang yang khawatir terhadap tindak kejahatan cenderung tidak mempercayai polisi karena merasa bahwa polisi tidak mampu menjamin keamanan dan keselamatannya (Boateng, 2012; Malone \& Dammert, 2020). Kontak seseorang dengan polisi berkaitan dengan kepercayaan terhadap polisi, dimana sikap polisi ketika melakukan kontak langsung dengan masyarakat memengaruhi pandangan masyarakat tersebut terhadap polisi (Ren et al., 2005). Hubungan dari faktor-faktor tersebut dengan status kepercayaan masyarakat kepada polisi digambarkan pada kerangka pikir berikut. 


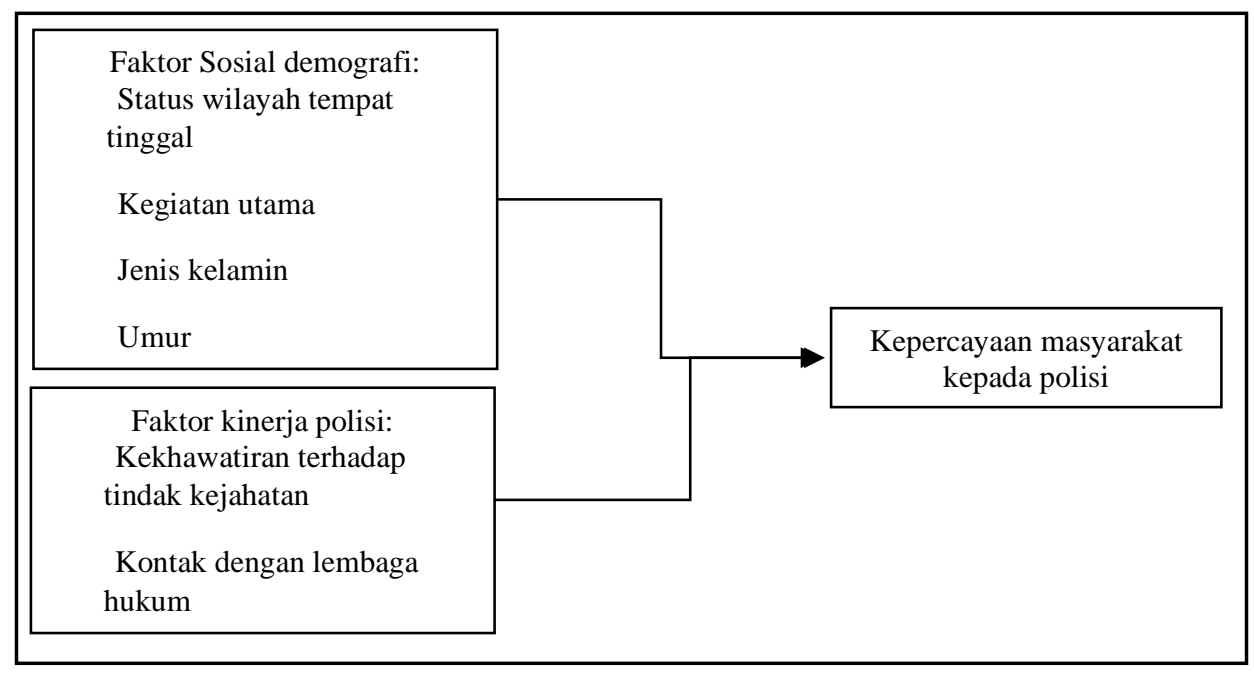

Gambar 3. Kerangka pikir penelitian

Metode analisis yang digunakan dalam penelitian ini adalah analisis deskriptif dan analisis inferensia. Analisis deskriptif dilakukan dengan menyajikan tabel dan gambar. Tabel dan gambar tersebut akan memberikan gambaran awal dari hubungan variabel respon dengan masing-masing variabel penjelas. Analisis inferensia dalam penelitian ini menggunakan metode analisis logistik biner, yaitu suatu metode analisis yang digunakan untuk melihat hubungan variabel penjelas baik berupa variabel kualitatif maupun kuantitatif dengan variabel respon yang bersifat dikotomi atau biner. Fungsi linier dari regresi logistik biasa disebut dengan fungsi logit dengan rumus sebagai berikut.

$g(x)=\beta_{0}+\beta_{1} x_{1}+\cdots+\beta_{p} x_{p}$

Model pada persamaan (1) hanya berlaku untuk regresi logistik dengan variabel penjelas berskala interval. Pada variabel penjelas berskala diskrit dilakukan modifikasi dengan variabel dummy dengan rumus sebagai berikut.

$g(x)=\beta_{0}+\beta_{1} x_{1}+\cdots+\sum_{I=1}^{k_{j}-1} \quad \beta_{j I} D_{j I}+\beta_{p} x_{p}$

Keterangan:

$g(x)$ : fungsi logit (fungsi linier dari regresi logistik)

$x \quad$ : variabel independen, $x=\left(x_{1}, x_{2}, \ldots, x_{p}\right)$

$\mathrm{p} \quad$ : jumlah parameter atau variabel penjelas

$\beta_{0}$ : intercept

$\beta_{j I}:$ koefisien variabel penjelas ke-j, dengan $j=1,2, \ldots, p$ dan $I=1,2, \ldots, k_{j} I$

$D_{j I} \quad$ : variabel penjelas , dengan $j=1,2, \ldots, p$ dan $I=1,2, . ., k_{j-} I$

Model regresi logistik biner untuk tujuh variabel penjelas kategorik dan satu variabel kontinu yang digunakan adalah sebagai berikut.

$\hat{g}(x)=\beta_{0}+\beta_{1} D_{1}+\beta_{21} D_{21}+\beta_{22} D_{22}+\beta_{23} D_{23}+\beta_{24} D_{24}+\beta_{3} D_{3}+\beta_{41} D_{41}+\beta_{42} D_{42}+\beta_{51} D_{51}+$

$\beta_{52} D_{52}+\beta_{53} D_{53}+\beta_{6} D_{6}+\beta_{7} X_{7}+\beta_{8} D_{8}$

Keterangan:

$\beta \quad$ : koefisien regresi

$D_{1} \quad$ : variabel dummy untuk wilayah tempat tinggal

$D_{21}$ : variabel dummy untuk kegiatan utama kategori sekolah

$D_{22}$ : variabel dummy untuk kegiatan utama kategori mengurus rumah tangga

$D_{23}$ : variabel dummy untuk kegiatan utama kategori lainnya

$D_{24}$ : variabel dummy untuk kegiatan utama kategori tidak ada

$D_{3} \quad$ : variabel dummy untuk jenis kelamin

$D_{41}$ : variabel dummy untuk umur kategori dewasa

$D_{42}$ : variabel dummy untuk umur kategori lansia

$D_{51}$ : variabel dummy untuk tingkat pendidikan kategori dasar

$D_{52}$ : variabel dummy untuk tingkat pendidikan kategori menengah

$D_{53}$ : variabel dummy untuk tingkat pendidikan kategori tinggi

$D_{6} \quad$ : variabel dummy untuk status ekonomi

$X_{7} \quad$ : variabel kekhawatiran terhadap tindak kejahatan

$D_{8} \quad$ : variabel dummy untuk status kontak 
Taraf signifikansi yang digunakan dalam penelitian ini adalah lima persen $(\alpha=0,05)$. Langkah-langkah analisis inferensia dalam penelitian ini adalah sebagai berikut.

1. Uji Simultan

Uji simultan dilakukan untuk mengetahui pengaruh variabel penjelas terhadap variabel respon secara bersama-sama (simultan). Uji ini dilakukan dengan Likelihood ratio test atau uji statistik G. Hipotesis yang digunakan dalam penelitian ini adalah sebagai berikut. polisi)

$\mathrm{H}_{0}: \beta_{1}=\beta_{2}=\ldots=\beta_{p}=0$ (Tidak ada variabel penjelas yang signifikan memengaruhi kepercayaan terhadap

$\mathrm{H}_{1}$ : minimal ada satu $\beta_{i} \neq 0$ (Minimal ada satu variabel penjelas yang signifikan memengaruhi kepercayaan terhadap polisi)

di mana $\mathrm{i}=1,2, \ldots, \mathrm{p}$

$G=-2 \ln \left[\frac{L_{0}}{L_{1}}\right]=-2\left(\ln \ln \left(L_{0}\right)-\right.$ $\left.\ln \ln \left(L_{1}\right)\right)$

Keterangan:

$L_{0}$ : fungsi maksimum likelihood tanpa variabel penjelas

$L_{1}$ : fungsi maksimum likelihood dengan variabel penjelas

$\mathrm{H}_{0}$ ditolak ketika nilai $G>\chi_{(0,05 ; 14)}^{2}$ atau jika $p$-value $<0,05$. Derajat bebas yang digunakan dalam pengujian ini adalah selisih parameter dari model tanpa variabel penjelas dan model dengan variabel penjelas. Ketika $\mathrm{H}_{0}$ ditolak menunjukkan bahwa minimal ada satu variabel penjelas yang signifikan terhadap kepercayaan kepada polisi.

2. Uji Parsial

Uji parsial digunakan untuk menguji signifikansi masing-masing variabel penjelas terhadap variabel respon secara parsial. Uji ini dilakukan dengan Uji Wald $(W)$. Hipotesis yang digunakan dalam uji parsial adalah sebagai berikut.

$\mathrm{H}_{0}: \beta_{j}=0$ (tidak ada pengaruh signifikan antara variabel penjelas ke- $i$ terhadap kepercayaan kepada polisi)

$\mathrm{H}_{1}: \beta_{j} \neq O$ (ada pengaruh signifikan antara variabel penjelas ke-i terhadap kepercayaan kepada polisi)

di mana $\mathrm{j}=1,2, \ldots, \mathrm{p}$

$W_{j}=\frac{\widehat{\beta}_{j}}{S E\left(\widehat{\beta}_{j}\right)}$.

Keterangan:

$\widehat{\beta}_{j} \quad$ : penduga parameter ke- $j$

$S E\left(\hat{\beta}_{j}\right)$ : standar error penduga parameter ke-j

$\mathrm{H}_{0}$ ditolak ketika nilai $W_{j}>\chi^{2}{ }_{(0,05 ; 1)}$ atau jika p-value $<0,05$. Ketika $\mathrm{H}_{0}$ ditolak maka dapat dikatakan bahwa variabel penjelas ke- $i$ signifikan memengaruhi kepercayaan terhadap polisi.

3. Uji Kesesuaian Model

Uji kesesuaian model atau Goodness of fit dilakukan untuk mengetahui apakah model yang model yang diajukan sesuai/cocok untuk menjelaskan hubungan antara variabel penjelas yang digunakan dengan kepercayaan masyarakat terhadap polisi di Indonesia tahun 2017. Uji ini dilakukan dengan statistik uji Hosmer dan Lemeshow. Hipotesis pengujiannya adalah sebagai berikut:

$\mathrm{H}_{0}$ : model sesuai (tidak ada perbedaan antara hasil observasi dan hasil prediksi model)

$\mathrm{H}_{1}$ : model tidak sesuai (ada perbedaan antara hasil observasi dan hasil prediksi model)

$\hat{C}=$

$\sum_{k=1}^{g} \quad \frac{\left(o_{k}-n_{k}^{\prime} \underline{\pi}_{k}\right)^{2}}{n_{k}^{\prime} \underline{\pi}_{k}\left(1-\underline{\pi}_{k}\right)}$

Keterangan:

$o_{k}:$ jumlah nilai variabel respon pada kelompok ke- $k$

$n_{k}^{\prime}$ : banyaknya observasi pada kelompok ke- $k$

$\underline{\pi}_{k}$ : rata-rata peluang estimasi untuk kelompok ke- $k$

$g$ : banyaknya kelompok

$\mathrm{H}_{0}$ ditolak ketika nilai $\hat{C}>\chi^{2}{ }_{(0,05 ; 8)}$ atau p-value $<0,05$. Derajat bebas pada penelitian ini adalah jumlah kelompok dikurangi dua $(g-2)$. Ketika $\mathrm{H}_{0}$ ditolak maka dapat dikatakan bahwa model yang terbentuk tidak sesuai atau terdapat perbedaan antara hasil observasi dan hasil prediksi model, pada uji ini diharapkan keputusan gagal tolak $\mathrm{H}_{0}$ sehingga dapat disimpulkan bahwa model yang terbentuk sesuai untuk menjelaskan hubungan antara variabel penjelas yang digunakan dengan kepercayaan kepada polisi di Indonesia tahun 2017. 


\section{Odds Ratio}

Odds ratio atau rasio kecenderungan digunakan untuk mengetahui seberapa besar kemungkinan atau ketidakmunkinan mengalami suatu kejadian tertentu antara kategori yang satu dengan kategori lainnya dalam suatu variabel, dengan kata lain rasio kecenderungan digunakan untuk mengetahui kecenderungan seseorang untuk percaya atau tidak percaya kepada polisi. Rasio kecenderungan membandingkan antara dua nilai odds pada saat $x_{j}=1$ dan $x_{j}=0$. Rasio kecenderungan diinterpretasikan sebagai kecenderungan terjadinya peristiwa $\mathrm{y}=1$ pada kategori $x_{j}=1$ sebesar $\exp \exp \left(\widehat{\beta}_{j}\right)$ kali terjadinya peristiwa $\mathrm{y}=1$ pada kategori $x_{j}=0$.

\section{Data dan Sumber Data}

Penelitian ini merupakan penelitian cross sectional dengan menggunakan data sekunder yang bersumber dari Badan Pusat Statistik (BPS). Data yang digunakan adalah raw data Susenas September 2017 modul Ketahanan Sosial (Hansos) dan modul Konsumsi/Pengeluaran (KP). Cakupan wilayah dalam penelitian ini adalah seluruh wilayah Indonesia. Unit analisis penelitian ini adalah penduduk yang berusia 18 tahun ke atas sebanyak 72.452 penduduk. Variabel-variabel yang digunakan dalam penelitian ini dapat dilihat pada Tabel 1 berikut.

Tabel 1. Daftar variabel yang digunakan.

\begin{tabular}{|c|c|}
\hline Nama Variabel & Keterangan \\
\hline \multicolumn{2}{|l|}{ Variabel Respon } \\
\hline Kepercayaan terhadap polisi (Y) & $\begin{array}{l}\text { 0: Tidak percaya } \\
\text { 1: Percaya }\end{array}$ \\
\hline \multicolumn{2}{|l|}{ Variabel Penjelas (Faktor Sosial Demografi) } \\
\hline Status wilayah tempat tinggal $\left(D_{1}\right)$ & $\begin{array}{l}\text { 0: Perkotaan } \\
\text { 1: Perdesaan }\end{array}$ \\
\hline Kegiatan utama $\left(\mathrm{D}_{2}\right)$ & $\begin{array}{l}\text { 0: Bekerja } \\
\text { 1: Sekolah } \\
\text { 2: Mengurus rumah tangga } \\
\text { 3: Lainnya } \\
\text { 4: Tidak ada }\end{array}$ \\
\hline Jenis kelamin $\left(D_{3}\right)$ & $\begin{array}{l}\text { 0: Laki-Laki } \\
\text { 1: Perempuan }\end{array}$ \\
\hline $\operatorname{Umur}\left(\mathrm{D}_{4}\right)$ & $\begin{array}{l}\text { 0: Remaja (18-25 tahun) } \\
\text { 1: Dewasa (26-45 tahun) } \\
\text { 2: Lansia (46 tahun ke atas) }\end{array}$ \\
\hline Tingkat pendidikan $\left(\mathrm{D}_{5}\right)$ & $\begin{array}{l}\text { 0: Pendidikan rendah }(<\mathrm{SD}) \\
\text { 1: Pendidikan dasar }(\mathrm{SD}-\mathrm{SMP}) \\
\text { 2: Pendidikan menengah }(\mathrm{SMA}) \\
\text { 3: Pendidikan tinggi }(>\mathrm{SMA})\end{array}$ \\
\hline Status ekonomi $\left(\mathrm{D}_{6}\right)$ & $\begin{array}{l}0: \text { Miskin }(<\mathrm{GK}) \\
1: \text { Tidak miskin }(\geq \mathrm{GK})\end{array}$ \\
\hline
\end{tabular}

\footnotetext{
Variabel Penjelas (Faktor Kinerja Polisi)
}

Tingkat kekhawatiran terhadap tindak kejahatan $\left(\mathrm{X}_{7}\right) \quad$ Kontinu (0-20)

Status Keterlibatan dengan Lembaga Hukum $\left(\mathrm{D}_{8}\right) \quad$ 0: Belum pernah

1: Pernah 


\section{HASIL DAN PEMBAHASAN}

\section{Gambaran umum kepercayaan masyarakat terhadap polisi di Indonesia}

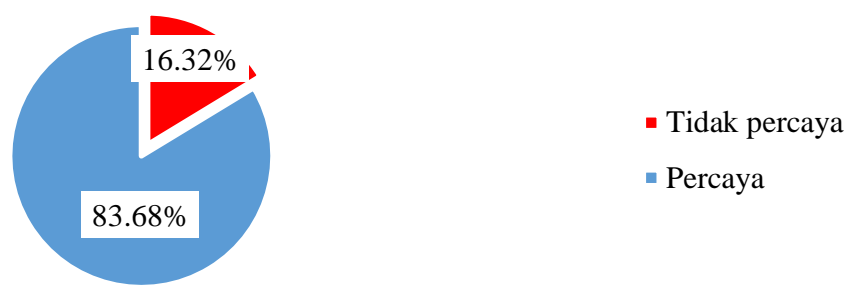

Sumber: Susenas Modul Hansos 2017, diolah

Gambar 4. Persentase kepercayaan masyarakat terhadap polisi di Indonesia tahun 2017

Berdasarkan hasil pengolahan data Susenas Hansos 2017 (Gambar 4), dapat diketahui bahwa 83,68 persen penduduk Indonesia pada tahun 2017 percaya kepada polisi. Persentase ini menunjukkan adanya kepercayaan masyarakat yang besar kepada instansi polisi. Meski demikian, keluhan masyarakat terkait kinerja polisi masih tinggi. Provinsi Nusa Tenggara Timur memiliki persentase kepercayaan kepada polisi tertinggi di Indonesia, yaitu sebesar 94,27 persen. Persentase kepercayaan kepada polisi terendah berada di Provin si Lampung dengan persentase kepercayaan kepada polisi sebesar 73,92 persen. Gambar 5 menunjukkan peta tematik dengan 3 kategori (rendah, sedang, dan tinggi) berdasarkan natural break persentase kepercayaan kepada polisi di Indonesia. Pada peta tersebut terlihat bahwa persentase kepercayaan kepada polisi rendah berada di Provinsi Jawa Timur, Kalimantan Utara, Papua, dan hampir seluruh provinsi di Sumatera.

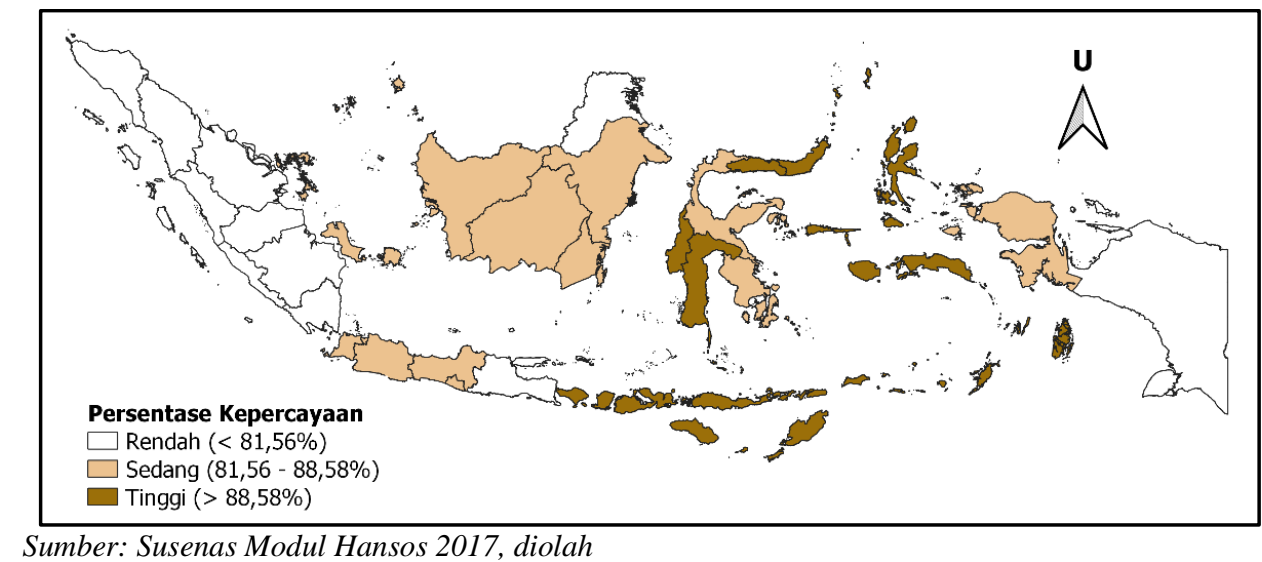

Gambar 5. Persentase kepercayaan masyarakat terhadap polisi berdasarkan masing-masing provinsi di Indonesia tahun 2017

Tabel 2. Persentase kepercayaan masyarakat terhadap polisi menurut masing-masing variabel penjelas.

\begin{tabular}{cccccc}
\hline \multirow{2}{*}{ Variabel } & Kategori & \multicolumn{2}{c}{ Jumlah } & \multirow{2}{*}{ Tidak Percaya } & Percaya \\
\cline { 3 - 4 } Faktor Sosial Demografi & & $\mathrm{n}=72.452$ & Persentase & & \\
\cline { 3 - 4 } Status Wilayah & Perkotaan & 31.118 & $42,95 \%$ & $17,64 \%$ & $82,36 \%$ \\
& Perdesaan & 41.334 & $57,05 \%$ & $15,32 \%$ & $84,68 \%$ \\
& Bekerja & 42.220 & $58,27 \%$ & $16,29 \%$ & $83,71 \%$ \\
Kegiatan Utama & Sekolah & 620 & $0,86 \%$ & $21,61 \%$ & $78,39 \%$ \\
& Mengurus rumah tangga & 27.884 & $38,49 \%$ & $16,22 \%$ & $83,78 \%$ \\
& Lainnya & 962 & $1,33 \%$ & $19,23 \%$ & $80,77 \%$ \\
Jenis Kelamin & Tidak ada & 766 & $1,06 \%$ & $13,58 \%$ & $86,42 \%$ \\
& Laki-laki & 26.275 & $36,27 \%$ & $17,38 \%$ & $82,62 \%$ \\
Umur & Perempuan & 46.177 & $63,73 \%$ & $15,72 \%$ & $84,28 \%$ \\
& Remaja & 4.896 & $6,76 \%$ & $18,40 \%$ & $81,60 \%$ \\
\hline
\end{tabular}




\begin{tabular}{cccccc}
\hline & Dewasa & 36.588 & $50,50 \%$ & $17,68 \%$ & $82,32 \%$ \\
& Lansia & 30.968 & $42,74 \%$ & $14,39 \%$ & $85,61 \%$ \\
& Rendah & 14.227 & $19,64 \%$ & $13,67 \%$ & $86,33 \%$ \\
Tingkat & Dasar & 33.828 & $46,69 \%$ & $15,92 \%$ & $84,08 \%$ \\
Pendidikan & Menengah & 17.311 & $23,89 \%$ & $18,97 \%$ & $81,03 \%$ \\
& Tinggi & 7.086 & $9,78 \%$ & $17,06 \%$ & $82,94 \%$ \\
\multirow{2}{*}{ Status Ekonomi } & Miskin & 1.159 & $1,60 \%$ & $11,22 \%$ & $88,78 \%$ \\
\multirow{2}{*}{ Faktor Kinerja Polisi } & Tidak miskin & 71.293 & $98,40 \%$ & $16,40 \%$ & $83,60 \%$ \\
& & & & \\
\multirow{2}{*}{ Kekhawatiran } & Cenderung tidak & 48.739 & $67,27 \%$ & $15,57 \%$ & $84,43 \%$ \\
& $(\leq 10)$ & & & \\
& Cenderung iya (>10) & 23.713 & $32,73 \%$ & $17,87 \%$ & $82,13 \%$ \\
Status Kontak & Belum pernah & 69.680 & $96,17 \%$ & $15,94 \%$ & $84,06 \%$ \\
& Pernah & 2.772 & $3,83 \%$ & $25,97 \%$ & $74,03 \%$ \\
\hline
\end{tabular}

Sumber: Susenas September 2017 (diolah)

Tabel 2 menunjukkan persentase kepercayaan kepada polisi menurut masing-masing variabel penjelas. Faktor sosial demografi terdiri dari variabel wilayah tempat tinggal, kegiatan utama, jenis kelamin, umur, tingkat pendidikan, dan status ekonomi. Pada variabel wilayah tempat tinggal, persentase masyarakat perkotaan yang percaya kepada polisi adalah sebesar 82,36 persen. Persentase masyarakat perdesaan yang percaya kepada polisi lebih tinggi dibanding masyarakat perkotaan yaitu sebesar 84,68 persen. Hal ini mengindikasikan bahwa masyarakat perdesaan cenderung lebih percaya kepada polisi dibanding masyarakat perkotaan. Berdasarkan kegiatan utama, persentase kepercayaan kepada polisi paling besar terdapat pada masyarakat yang tidak memiliki kegiatan utama, yaitu sebesar 86,42 persen. Kemudian disusul oleh masyarakat dengan kegiatan utama mengurus rumah tangga, bekerja, lainnya, dan sekolah berturut-turut sebesar 83,78 persen, 83,71 persen, 80,77 persen dan 38,39 persen. Masyarakat berjenis kelamin laki-laki memiliki persentase kepercayaan kepada polisi sebesar 82,62 persen. Sedangkan masyarakat berjenis kelamin perempuan memiliki persentase kepercayaan kepada polisi lebih tinggi dibanding laki-laki yaitu sebesar 84,28 persen. Hal ini mengindikasikan bahwa penduduk perempuan cenderung lebih percaya kepada polisi dibanding penduduk laki-laki. Persentase kepercayaan kepada polisi berdasarkan umur menunjukkan bahwa semakin bertambahnya umur maka persentase kepercayaan kepada polisi semakin tinggi. Persentase kepercayaan kepada polisi terendah berada pada kategori remaja yaitu sebesar 81,60 persen, disusul dengan kategori dewasa dan lansia secara berturut-turut sebesar 82,32 persen dan 85,61 persen. Kepercayaan masyarakat kepada polisi menurut tingkat pendidikan menunjukkan bahwa kategori pendidikan rendah memiliki persentase kepercayaan kepada polisi tertinggi, yaitu sebesar 86,33 persen. Selanjutnya disusul oleh pendidikan dasar, pendidikan tinggi, dan pendidikan menengah secara berturut-turut sebesar 84,08 persen, 82,94 persen, dan 81,03 persen. Meskipun pada kategori pendidikan tinggi persentase kepercayaan lebih tinggi dibanding kategori pendidikan menengah, namun selisih keduanya tidak terlalu jauh dan masih berada dibawah kategori pendidikan dasar. Hal ini mengindikasikan bahwa terdapat kecenderungan di mana semakin tinggi tingkat pendidikan maka kepercayaannya kepada polisi semakin menurun. Berdasarkan status ekonomi, persentase kepercayaan terhadap polisi pada penduduk miskin lebih tinggi dibanding penduduk tidak miskin. Penduduk tidak miskin memiliki persentase kepercayaan kepada polisi sebesar 83,60 persen sedangkan penduduk miskin memiliki persentase kepercayaannya kepada polisi sebesar 88,78 persen.

Pada faktor kinerja polisi, masyarakat yang cenderung khawatir terhadap tindak kejahatan memiliki persentase kepercayaan kepada polisi lebih rendah dibanding masyarakat yang cenderung tidak khawatir terhadap tindak kejahatan. Masyarakat yang cenderung tidak khawatir terhadap tindak kejahatan memiliki persentase kepercayaan kepada polisi sebesar 84,43 persen dan masyarakat yang cenderung khawatir terhadap tindak kejahatan memiliki persentase kepercayaan kepada polisi sebesar 82,13 persen. Menurut keterlibatan dengan lembaga penegak hukum, masyarakat yang pernah berurusan dengan lembaga hukum memiliki persentase kepercayaan kepada polisi lebih rendah dibanding masyarakat yang belum pernah berurusan dengan lembaga hukum. Masyarakat yang belum pernah berurusan dengan lembaga hukum memiliki persentase kepercayaan sebesar 84, 06 persen sedangkan yang pernah berurusan dengan lembaga hukum memiliki tingkat kepercayaan sebesar 74,03 persen. 


\section{Pengaruh Faktor Sosial Demografi dan Faktor Kinerja Polisi terhadap Kepercayaan kepada Polisi}

Uji Signifikansi Parameter Simultan

Uji simultan yang dilakukan pada penelitian ini untuk mengetahui apakah variabel penjelas secara bersama-sama berpengaruh terhadap variabel respon yaitu kepercayaan kepada polisi. Nilai chi-square tabel dengan $\alpha$ sebesar 0,05 dan derajat bebas 14 adalah 23,685 $\left(\chi_{(0,05,14)}^{2}=23,685\right)$. Tabel 3 menunjukkan bahwa nilai uji statistik $G$ adalah 591,863 di mana nilai tersebut lebih besar daripada nilai chi-square tabel. Selain itu, nilai p-value atau signifikansinya kurang dari 0,05 . Hal ini menunjukkan bahwa uji signifikansi parameter secara simultan menunjukkan hasil Tolak H0. Dengan demikian dapat disimpulkan bahwa dengan tingkat signifikansi 5 persen, minimal terdapat satu variabel penjelas yang secara signifikan memengaruhi kepercayaan kepada polisi di Indonesia tahun 2017.

Tabel 3. Hasil uji simultan.

\begin{tabular}{cccc}
\hline Deviance & Chi-square & Derajat bebas & P-value \\
\hline Step & 591,863 & 14 & 0,000 \\
Block & 591,863 & 14 & 0,000 \\
Model & 591,863 & 14 & 0,000 \\
\hline
\end{tabular}

Sumber: Susenas September 2017 (diolah)

Uji Signifikansi Parameter Parsial

Pada uji simultan diketahui bahwa minimal terdapat satu variabel penjelas yang secara signifikan memengaruhi kepercayaan kepada polisi. Selanjutnya dilakukan pengujian signifikansi variabel penjelas secara parsial untuk mengetahui variabel apa saja yang memengaruhi kepercayaan kepada polisi secara signifikan. Uji parameter secara parsial dilakukan dengan uji Wald $(W)$ dengan hasil yang dapat dilihat pada Tabel 4 berikut.

Tabel 4. Hasil uji parsial.

\begin{tabular}{|c|c|c|c|c|c|}
\hline Variabel & $\beta$ & Wald & $\mathrm{df}$ & $P$-value & $\operatorname{Exp}(\beta)$ \\
\hline Konstanta & 2,017 & 354,772 & 1 & $0,000^{*}$ & 7,517 \\
\hline \multicolumn{6}{|l|}{ Faktor Sosial Demografi } \\
\hline \multicolumn{6}{|l|}{ Status wilayah } \\
\hline \multicolumn{6}{|l|}{ Perkotaan ${ }^{r e f}$} \\
\hline Perdesaan $\left(D_{1}\right)$ & 0,118 & 30,425 & 1 & $0,000 *$ & 1,125 \\
\hline Kegiatan utama & & 12,133 & 4 & $0,016^{*}$ & \\
\hline \multicolumn{6}{|l|}{ Bekerja $^{r e f}$} \\
\hline Sekolah $\left(D_{21}\right)$ & $-0,128$ & 1,441 & 1 & 0,230 & 0,880 \\
\hline Mengurus rumah tangga $\left(D_{22}\right)$ & $-0,059$ & 5,461 & 1 & $0,019^{*}$ & 0,943 \\
\hline Lainnya $\left(D_{23}\right)$ & $-0,177$ & 4,480 & 1 & $0,034^{*}$ & 0,838 \\
\hline Tidak ada $\left(D_{24}\right)$ & 0,127 & 1,402 & 1 & 0,236 & 1,135 \\
\hline \multicolumn{6}{|l|}{ Jenis kelamin } \\
\hline \multicolumn{6}{|l|}{ Laki-laki $^{r e f}$} \\
\hline Perempuan $\left(D_{3}\right)$ & 0,197 & 62,685 & 1 & $0,000^{*}$ & 1,218 \\
\hline Umur & & 89,322 & 2 & $0,000 *$ & \\
\hline \multicolumn{6}{|l|}{ Remaja $^{\text {ref }}$} \\
\hline Dewasa $\left(D_{41}\right)$ & $-0,004$ & 0,009 & 1 & 0,922 & 0,996 \\
\hline Lansia $\left(D_{42}\right)$ & 0,205 & 21,655 & 1 & $0,000^{*}$ & 1,228 \\
\hline Tingkat pendidikan & & 41,595 & 3 & $0,000 *$ & \\
\hline \multicolumn{6}{|l|}{ Rendah $^{\text {ref }}$} \\
\hline $\operatorname{Dasar}\left(D_{51}\right)$ & $-0,070$ & 5,595 & 1 & $0,018^{*}$ & 0,932 \\
\hline Menengah $\left(D_{52}\right)$ & $-0,202$ & 35,696 & 1 & $0,000^{*}$ & 0,817 \\
\hline Tinggi $\left(D_{53}\right)$ & $-0,096$ & 5,220 & 1 & $0,022 *$ & 0,908 \\
\hline \multicolumn{6}{|l|}{ Status ekonomi } \\
\hline \multicolumn{6}{|l|}{ Miskin $^{\text {ref }}$} \\
\hline Tidak miskin $\left(D_{6}\right)$ & $-0,375$ & 15,843 & 1 & $0,000 *$ & 0,688 \\
\hline
\end{tabular}




\begin{tabular}{lccccc}
\hline Faktor Kinerja Polisi & & & & \\
$\quad$ Khawatir $\left(x_{7}\right)$ & $-0,017$ & 75,893 & 1 & $0,000^{*}$ & 0,983 \\
$\begin{array}{l}\text { Status kontak } \\
\quad \text { Belum pernah }\end{array}$ & & & & & \\
$\quad$ Pefnah $\left(D_{8}\right)$ & $-0,553$ & 152,179 & 1 & $0,000^{*}$ & 0,575 \\
\hline
\end{tabular}

Keterangan: ref = kategori referensi, *=signifikan pada taraf signifikansi sebesar 0,05

Variabel yang berpengaruh signifikan terhadap kepercayaan polisi adalah variabel dengan nilai Wald $(W)$ lebih dari nilai $\chi_{(0,05 ; 1)}^{2}$ atau nilai p-value kurang dari taraf signifikansi yang ditentukan $(0,05)$. Nilai chisquare tabel dengan $\alpha$ sebesar 0,05 dan derajat bebas 1 adalah $3,841\left(\chi_{(0,05,1)}^{2}=3,841\right)$. Berdasarkan tabel 4 , terlihat bahwa semua variabel penjelas pada faktor sosial demografi maupun faktor kinerja polisi memiliki nilai Wald $(W)$ lebih dari 3,841 dan nilai p-value kurang dari 0,05. Hal ini menunjukkan bahwa hasil keputusan uji Wald adalah Tolak H0. Sehingga dapat disimpulkan bahwa dengan tingkat signifikansi 5 persen, variabel pada faktor sosial demografi maupun faktor kinerja polisi meliputi status wilayah, kegiatan utama, jenis kelamin, umur, tingkat pendidikan, status ekonomi, kekhawatiran, dan status kontak berpengaruh secara signifikan terhadap kepercayaan kepada polisi. Berdasarkan Tabel 4, persamaan tranformasi logit yang terbentuk adalah sebagai berikut.

$$
\begin{aligned}
\hat{g}(x)=2,017 & +0,118 D_{1}{ }^{*)}-0,128 D_{21}-0,059 D_{22}{ }^{*)}-0,177 D_{23}{ }^{*)}+0,127 D_{24}+0,197 D_{3}{ }^{*)}-0,004 D_{41} \\
& +0,205 D_{42}{ }^{*)}-0,070 D_{51}{ }^{*)}-0,202 D_{52}{ }^{*)}-0,096 D_{53}{ }^{*)}-0,375 D_{6}{ }^{*)}-0,017 x_{7}{ }^{*)} \\
& \left.-0,553 D_{8}{ }^{*}\right)
\end{aligned}
$$

Uji Kesesuaian Model (Goodness of Fit)

Uji kesesuaian model dilakukan dengan uji Hosmer dan Lemeshow $(\hat{C})$ untuk mengetahui apakah model yang diajukan sudah sesuai untuk menjelaskan hubungan antara variabel penjelas dengan variabel respon. Nilai $\chi_{(0,05,8)}^{2}$ adalah 15,507. Berdasarkan Tabel 5, nilai $\hat{C}$ yang didapat adalah sebesar 10,730 . Nilai tersebut lebih kecil dibandingkan nilai chi- square tabel dan nilai p-value-nya lebih besar dibandingkan 0,05 . Dengan demikian dapat disimpulkan bahwa hasil pengujian adalah gagal tolak $\mathrm{H}_{0}$. Dengan tingkat signifikansi 5 persen, dapat disimpulkan bahwa model yang diajukan sudah cocok/sesuai untuk menjelaskan hubungan antara variabel penjelas yang digunakan dengan kepercayaan kepada polisi di Indonesia.

Tabel 5. Uji kesesuaian model

\begin{tabular}{ccc}
\hline Chi-square & df & $P$-value \\
\hline 10,730 & 8 & 0,217 \\
\hline
\end{tabular}

\section{Kecenderungan Karakteristik Individu Terhadap Kepercayaan Kepada Polisi}

Besarnya kecenderungan mengalami suatu kejadian tertentu antara kategori yang satu dengan kategori lainnya dalam suatu variabel dapat diketahui dengan nilai odds ratio atau nilai $\exp (\hat{\beta})$. Untuk memudahkan interpretasi, pada variabel yang berhubungan negatif dengan kepercayaan kepada polisi atau nilai $\exp (\hat{\beta})$ kurang dari satu, maka variabel tersebut akan diinterpretasikan secara terbalik dengan menghitung $1 / \exp (\hat{\beta})$. Berdasarkan tabel 4, interpretasi dari odds ratio adalah sebagai berikut.

1. Wilayah tempat tinggal

Berdasarkan hasil uji signifikansi regresi logistik secara parsial, diketahui bahwa variabel wilayah tempat tinggal berpengaruh secara signifikan terhadap kepercayaan kepada polisi ( $p$-value $=0,000)$. Nilai odds ratio dari variabel wilayah tempat tinggal adalah 1,125. Hal ini berarti penduduk yang tinggal di wilayah perdesaan memiliki kecenderungan untuk percaya kepada polisi 1,12 kali lebih besar dibanding penduduk yang tinggal di wilayah perkotaan. Hasil penelitian ini sejalan dengan penelitian Malone dan Dammert (2020) yang menyatakan bahwa penduduk yang tinggal di wilayah perdesaan lebih percaya kepada polisi dibandingkan penduduk yang tinggal di wilayah perkotaan. Menurut Weisheit et al., (1994), wilayah perdesaan cenderung memiliki tingkat kejahatan yang lebih rendah dibanding wilayah perkotaan sehingga apabila terjadi suatu tindak kejahatan di perdesaan maka polisi cepat menanganinya dibandingkan ketika tindak kejahatan tersebut terjadi di perkotaan. Oleh sebab itu, diharapkan seluruh anggota Kepolisian dapat membangun komitmen untuk memberikan pelayanan secara mudah, cepat, dan profesional. Selain itu, polisi juga diharapkan dapat meningkatkan kinerjanya dalam menurunkan tingkat risiko terkena kejahatan. 


\section{Kegiatan utama}

Pada variabel kegiatan utama, hanya penduduk dengan kegiatan utama mengurus rumah tangga ( $\mathrm{p}$ value $=0,019$ ) dan lainnya ( $\mathrm{p}$-value $=0,034$ ) yang signifikan berpengaruh terhadap kepercayaan kepada polisi. Nilai odds ratio dari penduduk yang mengurus rumah tangga adalah 0,943 , berarti penduduk yang bekerja memiliki kecenderungan 1,06 kali lebih besar untuk percaya kepada polisi dibandingkan penduduk yang mengurus rumah tangga. Untuk penduduk dengan kegiatan utama lainnya memiliki odds ratio sebesar 0,838 , berarti penduduk yang bekerja cenderung percaya kepada polisi 1,19 kali lebih besar dibandingkan penduduk dengan kegiatan utama lainnya. Hal ini sejalan dengan hasil penelitian Alahehto dan Larsson (2016) di mana penduduk yang bekerja memiliki kecenderungan lebih besar untuk percaya kepada polisi dibandingkan penduduk dengan kegiatan utama yang lain. Penduduk yang bekerja cenderung lebih sering keluar rumah dan memiliki tanggungan lebih besar dibandingkan penduduk dengan kegiatan utama yang lain. Hal ini dapat mengakibatkan orang yang bekerja merasa lebih membutuhkan perlindungan dari polisi dibanding kegiatan utama yang lain sehingga kepercayaannya kepada polisi cenderung lebih tinggi.

3. Jenis kelamin

Variabel jenis kelamin berpengaruh secara signifikan terhadap kepercayaan kepada polisi ( $\mathrm{p}$ value $=0,000$ ). Nilai odds ratio pada variabel ini adalah 1,218 , berarti penduduk perempuan memiliki kecenderungan untuk percaya kepada polisi 1,22 kali lebih besar dibandingkan penduduk laki-laki. Hasil ini sejalan dengan hasil penelitian Malone dan Dammert (2020) yang menyatakan bahwa penduduk perempuan cenderung lebih percaya kepada polisi. Menurut Statistik Kriminalitas 2018, pada tahun 2017 perbandingan korban kejahatan antara laki-laki dan perempuan adalah 2:1. Tingginya risiko mengalami tindak kejahatan pada laki-laki dan pelayanan polisi yang dinilai kurang memuaskan dapat mengakibatkan mereka merasa bahwa polisi tidak mampu menjamin keamanan dan keselamatannya.

4. Umur

Pada variabel umur, hanya kategori lansia yang berpengaruh signifikan terhadap kepercayaan kepada polisi ( $p$-value $=0,000$ ). Nilai odds ratio pada kategori lansia adalah sebesar 1,228 . Hal ini berarti penduduk lansia memiliki kecenderungan untuk percaya kepada polisi 1,23 kali lebih besar dibandingkan penduduk remaja. Hasil ini sejalan dengan hasil penelitian Malone dan Dammert (2020) yang menyatakan bahwa penduduk yang lebih tua cenderung lebih percaya kepada polisi. Menurut Ren et al., (2005) yang melakukan penelitian serupa, hal ini dapat disebabkan karena penduduk yang lebih muda cenderung memandang polisi sebagai institusi yang membatasi kemandirian mereka sehingga menilai polisi kurang baik dibandingkan penduduk yang lebih tua.

\section{Tingkat pendidikan}

Variabel tingkat pendidikan memiliki pengaruh signifikan terhadap kepercayaan kepada polisi untuk semua kategori. Kategori pendidikan dasar ( $p$-value $=0,018)$ memiliki odds ratio sebesar 0,932 . Hal ini berarti penduduk dengan pendidikan rendah memiliki kecenderungan untuk percaya kepada polisi 1,07 kali lebih besar dibandingkan penduduk dengan pendidikan dasar. Kategori pendidikan menengah ( $\mathrm{p}$-value $=0,000$ ) memiliki odds ratio sebesar 0,817 , berarti penduduk dengan pendidikan rendah memiliki kecenderungan untuk percaya kepada polisi 1,22 kali lebih besar dibandingkan penduduk dengan pendidikan menengah. Kategori pendidikan tinggi ( $\mathrm{p}$-value $=0,022$ ) memiliki odds ratio sebesar 0,908 , berarti penduduk dengan pendidikan rendah memiliki kecenderungan untuk percaya kepada polisi 1,10 kali lebih besar dibandingkan penduduk dengan pendidikan tinggi. Hasil ini sejalan dengan penelitian Malone dan Dammert (2020) di mana penduduk dengan tingkat pendidikan lebih tinggi cenderung lebih tidak percaya kepada polisi. Menurut Tankebe (2010) yang melakukan penelitian serupa, hal ini dapat terjadi karena penduduk dengan pendidikan yang lebih tinggi menjadi lebih melek hukum dan lebih kritis terhadap kinerja kepolisian.

\section{Status ekonomi}

Variabel status ekonomi memiliki pengaruh signifikan terhadap kepercayaan kepada polisi (pvalue $=0,000)$. Variabel ini memiliki odds ratio sebesar 0,688. Hal ini berarti penduduk miskin memiliki kecenderungan 1,45 kali lebih besar untuk percaya kepada polisi dibandingkan penduduk tidak miskin. Hasil penelitian ini bertolak belakang dengan penelitian Malone dan Dammert (2020) yang menyimpulkan bahwa semakin tinggi tingkat perekonomian seseorang maka tingkat kepercayaannya kepada polisi makin tinggi. Perbedaan hasil penelitian ini dapat disebabkan oleh adanya perbedaan geografis penelitian. Menurut Weisheit et al., (1994) seseorang dengan perekonomian yang lebih tinggi lebih berkemungkinan untuk menjadi korban kejahatan. Penanganan polisi terhadap tindak kejahatan yang dialami korban yang dinilai kurang memuaskan dapat menyebabkan orang tersebut menjadi tidak percaya kepada polisi.

7. Kekhawatiran

Variabel kekhawatiran terhadap tindak kejahatan memiliki pengaruh signifikan terhadap kepercayaan kepada polisi ( $\mathrm{p}$-value=0,000). Berdasarkan tabel 4, variabel kekhawatiran memiliki odds ratio sebesar 0,983. 
Hal ini berarti kecenderungan untuk percaya kepada polisi meningkat 1,02 kali setiap penurunan 1 skor kekhawatiran, dengan kata lain kecenderungan untuk percaya kepada polisi semakin meningkat seiring dengan berkurangnya rasa khawatir seseorang terhadap tindak kejahatan. Hasil ini sejalan dengan penelitian Malone dan Dammert (2020) yang menyatakan bahwa penduduk yang lebih tidak khawatir terhadap tindak kejahatan cenderung lebih percaya kepada polisi. Menurut Boateng (2012) yang melakukan penelitian serupa, hal ini disebabkan karena penduduk yang khawatir terhadap tindak kriminal memandang bahwa polisi tidak mampu memastikan keamanan dan keselamatan mereka. Ketidakpercayaan masyarakat terkait kinerja polisi menunjukkan bahwa perlu adanya pengawasan yang lebih ketat terhadap kinerja setiap lembaga penegak hukum

\section{Status kontak}

Berdasarkan hasil uji signifikansi regresi logistik secara parsial, variabel status kontak memiliki pengaruh signifikan terhadap kepercayaan kepada polisi $(\mathrm{p}$-value $=0,000$ ). Nilai odds ratio dari variabel ini adalah 0,575. Hal ini berarti penduduk yang belum pernah berurusan dengan lembaga hukum memiliki kecenderungan untuk percaya kepada polisi 1,74 kali lebih besar dibandingkan penduduk yang pernah berurusan dengan lembaga hukum. Hasil ini sejalan dengan penelitian Malone dan Dammert (2020) di mana penduduk yang pernah berurusan dengan lembaga hukum cenderung tidak percaya kepada polisi. Penilaian masyarakat terhadap polisi tergantung bagaimana mereka diperlakukan oleh polisi dan kemampuan polisi dalam menangani tindak kejahatan (Malone \& Dammert, 2020; Ren et al., 2005). Variabel keterlibatan dengan lembaga hukum merupakan variabel dengan kontribusi terbanyak dalam status kepercayaan kepada polisi, sehingga kepolisian diharapkan dapat meningkatkan kinerja serta performanya terutama yang berhubungan langsung dengan masyarakat.

\section{KESIMPULAN}

Berdasarkan hasil dan pembahasan dalam penelitian ini, dapat disimpulkan bahwa persentase kepercayaan masyarakat kepada polisi di Indonesia tergolong cukup tinggi. Provinsi dengan persentase kepercayaan rendah didominasi oleh provinsi yang berada di wilayah Sumatra di mana persentase kepercayaan terendah berada di Provinsi Lampung. Sedangkan persentase kepercayaan tertinggi berada di Provinsi Nusa Tenggara Barat. Faktor sosial demografi yang berpengaruh signifikan terhadap kepercayaan kepada polisi antara lain wilayah tempat tinggal, kegiatan utama, jenis kelamin, umur, tingkat pendidikan, dan status ekonomi. Sedangkan faktor kinerja polisi yang signifikan terhadap kepercayaan kepada polisi adalah kekhawatiran terhadap tindak kejahatan dan keterlibatan dengan lembaga penegak hukum. Penduduk yang tinggal di wilayah perdesaan, memiliki kegiatan utama bekerja, berjenis kelamin perempuan, lansia, berpendidikan rendah, berstatus miskin, tidak khawatir terhadap tindak kejahatan, dan tidak pernah berurusan dengan lembaga penegak hukum cenderung lebih percaya kepada polisi.

\section{DAFTAR PUSTAKA}

Alalehto, T., \& Larsson, D. (2016). Measuring trust in the police by contextual and individual factors. International Journal of Law, Crime and Justice, 46, 31-42. https://doi.org/10.1016/j.ijlcj.2016.01.001

Boateng, F. D. (2012). Public Trust in the Police: Identifying factors that shape trust in the Ghanaian Police (IPES Working Paper Series, No. 42). http://www.ipes.info/WPS/WPS_No_42.pdf

Dwiyanto, A. (2011). Mengembalikan Kepercayaan Publik Melalui Reformasi Birokrasi (1st ed.). Jakarta:PT Gramedia Pustaka Utama.

Goldsmith, A. (2005). Police reform and the problem of trust. Theoretical Criminology, 9(4), 443-470. https://doi.org/10.1177/1362480605057727

Kääriäinen, J. T. (2007). Trust in the police in 16 European countries: A multilevel analysis. European Journal of Criminology, 4(4), 409-435. https://doi.org/10.1177/1477370807080720

Lee, H. D., Cao, L., Kim, D., \& Woo, Y. (2019). Police contact and confidence in the police in a medium-sized city. International Journal of Law, Crime and Justice, 56(April 2018), 70-78. https://doi.org/10.1016/j.ijlcj.2018.12.003

Litbang Kompas. (2019). Survei Litbang Kompas 2018.

Malone, M. F. T., \& Dammert, L. (2020). The police and the public: policing practices and public trust in Latin America. Policing and Society, O(0), 1-16. https://doi.org/10.1080/10439463.2020.1744600

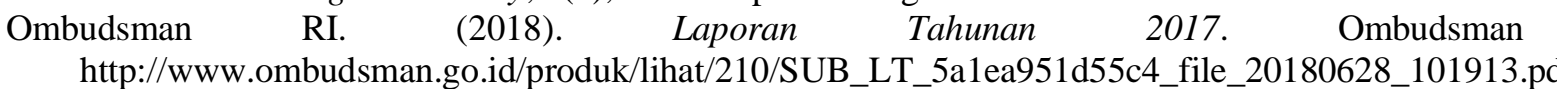


Ren, L., Cao, L., Lovrich, N., \& Gaffney, M. (2005). Linking confidence in the police with the performance of the police: Community policing can make a difference. Journal of Criminal Justice, 33(1), 55-66. https://doi.org/10.1016/j.jcrimjus.2004.10.003

Tankebe, J. (2010). Public confidence in the police: Testing the effects of public experiences of police corruption in Ghana. British Journal of Criminology, 50(2), 296-319. https://doi.org/10.1093/bjc/azq001

Komnas HAM 2013. (2014). Laporan Tahunan Komnas HAM 2013. Komnas HAM.

Komnas HAM 2014. (2015). Laporan Tahunan Komnas HAM 2014. Komnas HAM.

Komnas HAM 2015. (2016). Pemulihan Hak-Hak Korban Pelanggaran HAM : Laporan Tahunan Komnas HAM 2015. Komnas HAM.

Komnas HAM 2016. (2017). Pemenuhan Hak Kelompok Minoritas dan Rentan di Indonesia: Laporan Tahunan Komnas HAM 2016. Komnas HAM.

Komnas HAM 2017. (2017). Laporan Tahunan Komnas HAM 2017. Komnas HAM. https://www.komnasham.go.id/files/20180914-laporan-tahunan-komnas-ham-2017-\$80XP.pdf

Watkins, A. M. (2005). Examining the disparity between juvenile and adult victims in notifying the police: A study of mediating variables. Journal of Research in Crime and Delinquency, 42(3), 333-353. https://doi.org/10.1177/0022427805275186

Weisheit, R. A., Falcone, D. N., \& Wells, L. E. (1994). Rural Crime and Rural Policing. Research in Action, 1-15. https://www.ncjrs.gov/pdffiles/rcrp.pdf

Wu, Y., Poteyeva, M., \& Sun, I. Y. (2012). Trust in police: A comparison of China and Taiwan. International Journal of Comparative and Applied Criminal Justice, 36(3), 189-210. https://doi.org/10.1080/01924036.2012.699794 